\title{
Typology of Headedness in Yorùbá Nominal Derivations
}

\author{
Bisoye Eleshin \\ University of Lagos, Nigeria
}

\begin{abstract}
This study examines headedness in different nominalisation processes in Yorùbá. This research aims to investigate possible unification of head analysis in Yorùbá nominalisation. Three major word formation strategies exist in Yorùbá, namely, affixation, reduplication and nounnoun compounding (N-N compounding henceforth). The morphosyntactic relationship among these three, in respect to a unifying analytical goal, has not been fairly considered. Operation merge, with other principles of the Minimalist Programme, is selected to validate my claim about the unified analysis of headedness in Yorùbá. This paper employs the qualitative method of data collection. Data were
\end{abstract}

\footnotetext{
Bisoye Eleshin

Researcher, Institute of African and Diaspora Studies, University of Lagos, Nigeria

Email: bisoyeeleshin@gmail.com
}

Received 5 February, 2021; Revised 5 March, 2021; Accepted 23 March, 2021

Copyright (C) 2021 Language Research Institute, Sejong University Journal of Universal Language is an Open Access Journal. All articles are distributed online under the terms of the Creative Commons Attribution Non-Commercial License (http://creativecommons.org/licenses/by-nc/3.0) which permits unrestricted non-commercial use, distribution, and reproduction in any medium, provided the original work is properly cited. 
92 Typology of Headedness in Yorùbá Nominal Derivations

sourced from both primary and secondary means. I claim that there exists a parallel morphosyntactic structure for the three nominalisation processes in Yorùbá. I establish that the three nominalisation structures have the same syntactic representation as far as their headedness and their internal syntax is concerned. Findings in this study show that, firstly, prefixes, reduplicant and the first noun in an N-N compounding are the head. Secondly, they all occupy the same parallel positions in their varying structures.

Keywords: nominalisation, morpho-syntax, prefixation, reduplication, $\mathrm{N}-\mathrm{N}$ compounding, merge

\section{Introduction}

Morphology includes all the processes involved in word formation of a given language. It is the first stage where meaning is given considerable attention in language analysis and it also serves as an analytical point for the evaluation of syntax and semantics in any language (Lyons 1980). In the build-up of the morphological process, there are obvious interactions between bound and free morphemes, and between two or more free morphemes. The morphosyntactic analysis of the status of the morphemes is vital to head identification in any derivation (Táíwò 2014, Omachonu 2015, Caesar 2019). Headedness can be described as the identification of the central morpheme which is by distribution, equivalent to the phrase in a syntactic representation (Crystal 2008). In other words, the head of a nominal is equivalent to the phrasal class status of the whole derivation (Eleshin 2017).

One of the aspects of morphology in the field of linguistics is nominalisation. Going by the diverse definitions of nominalisation in the literature, nominalisation could be summarised as the process of 
forming nominals. Furthermore, for the purpose of this paper, I operationalise nominalisation to be any form of modification to any item belonging to a particular word class, noun inclusive, which results into nominals. This is particularly stated in order to cater for the process of noun-noun compound formation as one of the nominal derivations in Yorùbá. One of the main motivations for this study is an attempt to harmonise, thereby simplify the nominal formation strategies in Yorùbá. Although, considerable works have been done on the phonology and the internal syntax of nominalisation in the language (Awóyalé 1974; Owólabí 1976, 1984; Oyèláràn 1987; Pulleyblank \& Akinlabi 1988; Ògúnkẹ́yẹ 2002; Ajíbóyè et al. 2003; Awóbùlúyì 2008; Pulleyblank 2009; among others), not much has been done systematically at the morpho-syntactic level on the formation of nouns and especially on the possible unification of the process of noun formation.

Noun formation in Yorùbá can be categorised into three, namely; affixation, reduplication and noun-noun compounding (Taiwo 2006, Awobuluyi 2008, Ilori 2010). For affixation, the only type that is identified in Yorùbá language is prefixation. Infixation, suffixation and circumfixation do not exist in the language (Awóbùlúyì 2008: 3040). Thus, the distribution and syntactic analysis of prefixation is investigated. Also, the status of the prefixes in terms of headedness in a derived noun will be illustrated. There are two types of reduplication identified in Yoruba namely full reduplication and partial reduplication (Owólabí 1985, Ajibóyè \& Dechaine 2003, Pulleyblank 2009). Full reduplication involves the process of reduplicating an entire base in a word formation process, while partial reduplication involves the reduplication of part of an existing base in derivation. For compounding, it is the process of forming a word from two other words with noncompositional meaning (Táíwò 2014). The compound word is a 
94 Typology of Headedness in Yorùbá Nominal Derivations

combination of same or different classes of words. However, this study will focus on the process of deriving a compound noun from two collocating noun. These three derivation processes will be analysed and checked for a unified formation process. It is hoped that the outcome of this analysis will minimise the analytical processes involved in Yorùbá word formation. This speaks to the concept of the minimalist programme, i.e., minimising the number of rules required for grammatical analysis.

\section{Operation Merge and Its Properties}

Merge is an indispensable operation of a recursive system which takes two syntactic objects, $\mathrm{A}$ and $\mathrm{B}$, and forms the new object $\mathrm{C}$, with A and B as its immediate constituents (Chomsky 2001). It is an operation which forms larger units out of those already constructed in a grammatical structure (Crystal 2008; Collins 2011, 2013). Merge can be subcategorised into two: external and internal. External merge functions as the basic operation that takes two elements and makes them a set (McGilvary 2014). Internal merge on the other hand functions in a slightly different way because, apart from combining A and B, it draws B from within A (Adger \& Svenonius 2011). Modification of structure from one derivational step to another is regarded as internal merge. This is why 'move' has been seen under the Minimalist Programme to be a variant of 'merge' (Chomsky 2001). In a later development, Citko (2005) identified a third type of merge: Parallel Merge. Parallel Merge combines the properties of external merge and internal merge. It creates symmetric, multidominant structures, which become antisymmetric in the course of the derivation (Citko 2005: 475). 


\subsection{Merge in Yorùbá Morphology}

Merge is the main operation of the Minimalist Programme (Crystal 2008). There are three points to note in the application of merge in nominal derivation. First, the merging of the components involves binary branching only. This means that merge is a binary operation; the binary operation could be Spec-Head merge or Head-Complement merge. In either case, the branching does not exceed two. In cases where the lexemes are more than two, i.e., when derivation involves more than two morphemes, binary branching must first be established before the derived nominal can be merged with another morpheme. There is no unary or ternary branching where less or more than two items are merged. In cases where ternary branching is eminent, binary branching within the analysis is firstly identified (cf. Collins 2013).

(1)

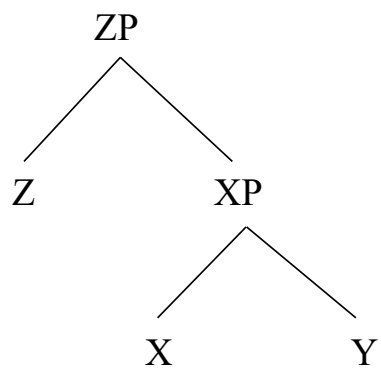

In the above structure, the $X Y$ merge occurs in which the $X$ projects to the phrasal level before the phrasal constituent functions as the complement to a segment $Z$. This type of construction is imminent in complex structures where more than two lexical items are involved (Collins 2013). It is important to note that complex structures like this behave the same way in three types of Yorùbá nominalisation processes. 
96 Typology of Headedness in Yorùbá Nominal Derivations

There are three levels of merge that can be identified in a nominal derivation:

(i) when two morphemes are merged: i- (prefix) and fẹ (love, V), they derive ifẹ (love, $\mathrm{N}$ ):

(2)

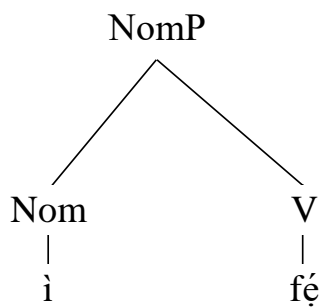

(ii) When a morpheme is merged with an already formed VP such as jedé (jẹ edé) 'eat crayfish' and fúrúgbin (fún irú ògbìn) 'sow a type of seed' to derive a nominal: ijedé 'act of eating crayfish' and afúrúgbin 'sower' respectively.

Consider (3a) and (3b) below:

(3)

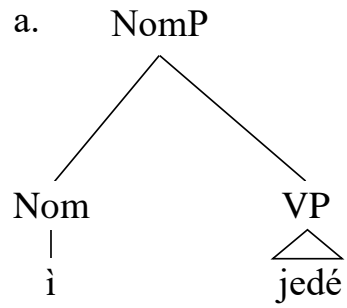

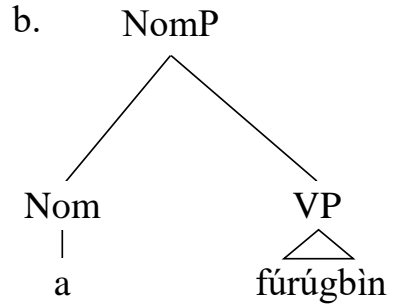

(iii) The third level of merge is when two VPs, initially formed, are merged: gbálè-gbálè 'sweeper' 


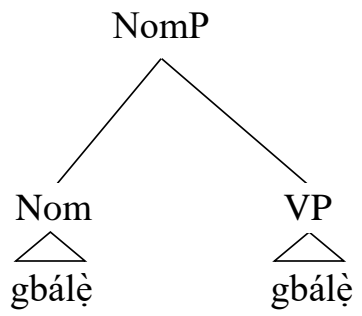

We should note that all the merging operations in (1)-(3) are achieved by binary branching. For instance, in a derived nominal, as in (3a), ijedé 'act of eating crayfish', the binary branching will first be established between je 'eat' and edé 'crayfish' before the resulting phrase merges with the prefix $i$.

The second point to note is that the derivational analysis is based on the endocentric property of operation merge. When two elements merge, the resulting phrase takes its syntactic category label from one of the two items. In Yorùbá nominal analysis, the resulting phrase takes its syntactic category label from the first element. This means that a derived phrase takes its category label from the left-sided nominal of the merged items.

For the third point, the word order of nominalisation involving the three types of derived nominals in Yorùbá suggests that the head is always followed by the complement. The orderliness of the elements is very significant to a successful merge operation. This explains the linear correspondence structure of the participating morphemes. The nominaliser is always followed by the complement. This is referred to as the $\operatorname{LCA}^{1}$ (Collins 2011). Therefore, all the root words serve as

\footnotetext{
1 The following abbreviations are used in this paper: LCA (linear correspondence axiom), Nom (nominaliser), NomP (nominaliser phrase), NP (noun phrase), VP (verb phrase), RED (reduplicant), PREF (prefix), neg (negator), sg (singular), HTS (high tone syllable), COMP (complement), LF (logical form), PF (phoretic form), spec (specifier).
} 
complements to the nominalising morpheme in the process of forming nominals in Yorùbá.

The three word formation processes that have been identified in this paper will be reviewed with the application of operation merge, to check whether they follow a uniform morphosyntactic derivational pattern. The aim of this research is to present a unified analysis for the structure of nominalisation, thereby reducing word formation rules in Yorùbá language.

\section{Methodology}

The method of data collection employed for this research is qualitative. Data gathered for this study include Yorùbá nominals, both derived and non-derived. The usage and distribution of the nominals are observed from native speakers of the language. The methodology splits into two. First, textual and library based methodology, and second, elicitation of data from native speakers of Yorùbá which includes the author. These methods provide an avenue for the development of ideas and hypotheses for further research opportunities.

Textual consultation was made using existing literary works on the grammar of the Yorùbá and various grammatical materials including works on universal grammatical theories and models of analysing different languages. These literatures added great value to this research as it was discovered that western linguists have carried out a lot of research exercise on many African languages, Yorùbá inclusive. 


\section{Headedness in Yorùbá Prefixation}

Prefixes are very essential to the whole process of nominal derivation by affixation. Undoubtedly, prefixation appears to be the only tenable affix in Yorùbá morphology. In the morphosyntactic derivational process, the prefix merges with the root word, which is always a VP. The structure of the root word could be monosyllabic, bisyllabic or polysyllabic.

Consider the following:
a. ìjẹ
ì-jẹ
PREF-eat
'something edible'
b. àjùlọ
à-jùlọ
PREF-senior
'seniority'
c. ọ̀ta
ò-ta
PREF-play
'skillful player'

The above data sets include the merge of prefixes and VP that are monosyllabic, bisyllabic and polysyllabic, as in (5a), (5b) and (5c) respectively.

The examples in (5) above are derived through prefixation. Note that endocentrically, one of the morphems that are merged to form a nominal shares the same word class with the derived nominal. In that case, the prefixes are identified as the head of the derived nominals. Thus, ì-, à- 
and ọ- are the head in derivation of ijẹ, àjùlo and òta respectively.

Furthermore, the semantic class of derived nouns can be used to identify the head morpheme. Consider the following derived nouns:

(6) a. ikú

i-kú

PREF-die

'death'

b. òkú

ò-kú

PREF-die

'dead (body)'

In the data sets above, the root morpheme is $k u$ in both (6a) and (6b). The semantic feature of the derived nouns is intrinsic in the prefixes that are merged with the root morpheme during the process of derivation.

Below are more sets of data that buttress this point:

(7) a. ibí

ì-bí

PREF-born

'birth'

b. òbí

ò-bí

PREF-born

'parent'

c. obí

o-bí

PREF-born

'female (specie)' 
d. ẹbí

ẹ-bí

PREF-born

'relative'

The derivations in (7) above provide an explicit presentation on the features of the prefixes that are merged with the same root word, $b i$. The semantics of the prefixes, ì-, ò-, o- and ẹ- provides the distinctiveness in the derivation of the nouns (7a)-(7d). This analysis has corroborated the prefix-head analysis of Yorùbà nouns derived by prefixation.

\subsection{Reduplication in Yorùbá}

Reduplication in Yorùbá can be categorised into full and partial reduplication. In this section, I present the analysis of nominalisation by full reduplication. The process of deriving reduplication in language involves copying (Pulleyblank 2009, Forza 2011, Ògúnwálé 2012, Eleshin 2017). Various scholars of Yorùbá word formation have identified different categories of full reduplication process (Pulleyblank \& Akinlabi 1988, Awóyalé 1989, Ọla 1995, Ajibóyè \& Dechaine 2004, Ògúnwálé 2012, Akinlabi \& Iloene 2015, Ehineni 2017). This study examines one of the numerous reduplication types that have already been established in Yorùbá language, namely agentive reduplication.

\subsubsection{Agentive Reduplication}

This type of reduplication is what was also referred to as professional reduplication in Awóyalé (1989). A significant feature of this reduplication type is that it describes a habitual act carried out by someone. The structure of the root of an agentive reduplication is at 
least CVCV consisting of a VP which is mostly a verb and its object, thus:

(8) $\mathrm{VP}_{\mathrm{Red}} \leftarrow \mathrm{VP} \rightarrow \mathrm{NP}$

The internal syntax of a derived nominal by reduplication is such that the root word (VP) is reduplicated to the left of the root and the reduplicated VP is considered as the nominaliser of the root word. The merge of the reduplicated VP and the root VP derive NP. Note also that this rule is not bidirectional, the VP is always reduplicated to the left. Since the process of copying in reduplication in Yorùbá is from right to left (Ola 1995, Bakovic 2003, among others.), it follows then, through language internal evidence, that in full reduplication, there is perfect identity correspondence between the reduplication and the root word. This explains that, in a derivation that involves reduplication, the left sided component is the copied morpheme.

Observe examples of this reduplication process below:
a. kộ ilé $\rightarrow$ kộlé $\rightarrow$ kộlé kộlé $\rightarrow$ kọllé-kộlé build house build-house RED-buildhouse 'builder'
b. pa eja $\rightarrow$ pẹja $\rightarrow$ pẹjapẹja $\rightarrow$ pẹja-pẹja kill fish kill-fish RED-kill-fish 'fisherman'
c. gbe ọmọ $\rightarrow$ gbọmmọ $\rightarrow$ gbọ́mogbọ́mọ $\rightarrow$ gbọ́mo-gbọ́mọ carry child carry-child RED-carry-child 'kidnapper'

One of the phenomena that interest us in this research is that the input of the derivation does not categorically correspond to the derived morpheme. The root and the reduplicating morpheme both have VP structure. It does not follow a normal syntactic interaction to have two VPs deriving a nominal in Yorùbá. As such, there are some 
possible syntactic possibilities during the process of derivation of this type of nominal. Thus, I present the following hypotheses:

(i) The reduplicated VP is a nominal that nominalises the root VP, this might be due to some activities of the LF or PF, or both, at Spell-Out.

(ii) There is a covert nominaliser that nominalises the reduplicated derivation at Spell-Out.

Now, I take a critical look at the two hypotheses and give a submission after which I stick to the one with lesser exceptions.

One of the points that can be used to provide justification for the first hypothesis is that, to a large extent, the reduplicant; which is also the left-sided copy of the derived nominal, has a parallel semantic notion with the agentive prefix $a$-.

Let us compare (10) and (11) below:

(10) a. rán aṣọ $\rightarrow$ ránșọ $\rightarrow$ ránșọánșọ $\rightarrow$ ránșọ-ránṣọ sew cloth sew-cloth RED-sew-cloth 'tailor'

b. pa ẹja $\rightarrow$ pẹja $\rightarrow$ pẹjapẹja $\rightarrow$ pẹja-pẹja kill fish kill-fish RED-kill-fish 'fisherman'

c. gbe ọmọ $\rightarrow$ gbọ́mọ $\rightarrow$ gbọ́mogbọ́mọ $\rightarrow$ gbọ́mo-gbọ́mọ carry child carry-child RED-carry-child 'kidnapper'

(11) a. rán aṣọ $\rightarrow$ ránșọ $\rightarrow$ a ránșọ $\rightarrow$ aránṣọ sew cloth sew-cloth PREF-sew-cloth 'tailor'

b. pa ẹja $\rightarrow$ pẹja $\rightarrow$ a-pẹja $\rightarrow \quad$ apẹja kill fish kill-fish PREF-kill-fish 'fisherman'

c. gbe ọmọ $\rightarrow$ gbọ́mọ $\rightarrow$ a- gbọ́mọ $\rightarrow$ agbọ́mọ carry child carry-child PREF-carry-child 'kidnapper' 
The derivations (10) and (11) possess a parallel structure. It has already been established above that the prefix $a$-is an agentive prefix. Note that reduplicative morpheme in (10) and the agentive prefix morpheme in (11) have the same syntactic distributions. With this understanding and the eventual outcome of the derivation, it adds up that the reduplicative morpheme in (10) and the agentive prefix morpheme in (11) possess the same semantic connotation.

At this stage, if I could be able to establish that these two morphemes have the same semantic connotation, and that they can be merged with a VP to derive a nominal, it means that they naturally nominalise their compliments which are always VP. For instance, there is no particular difference between (10a) and (11a); and (10b) and (11b).

Pulleyblank \& Akinlabi (1988) claim that reduplicative agentive prefixes and vowel agentive prefixes behave the same way in that they can be found in the same environment and therefore, they perform the same task in a derivational process. Ola (1995) argues against the above claim. Ola asserts that it is not in every VP case that the agentive prefix can do the work of the reduplicative morpheme.

Let us consider the following:
a. kó ilé $\rightarrow$ kólé $\rightarrow$ kólé-kólé $\rightarrow$ kólé-kólé carry house carry-house RED-carry-house 'thief'
b. jẹidi $\rightarrow$ jẹdí $\rightarrow$ jẹdí-jẹdí $\rightarrow$ jẹ̀dí-jẹdí eat butocks eat-buttocks RED-eat-buttocks 'pile'

(13)
a. kó ilé $\rightarrow$ kólé $\rightarrow$ a-kólé $\rightarrow \quad$ akólé carry house carry-house PREF-carry-house 'thief'
b. jẹ idí $\rightarrow$ jẹ̀dí $\rightarrow$ a-jẹddí $\rightarrow \quad$ ajẹdí eat buttocks eat-buttocks PREF-eat-buttocks 'pile' 
According to Ola (1995), the nominals in (13) are not acceptable in the language. As much as I might want to see reason with this assertion, the syntactic composition, in line with the semantics and syntax of the morphemes, appears to make me think otherwise. Inasmuch as there is no difference between the agentive prefix as shown in (11) and (13), and the syntax of the derivation in both data sets is also the same, I claim that the derivation is syntactically possible in the language. The nominals are well-formed in the interface and the merging process is well defined.

It is crucial to point out that in the language faculty of all humans, there is an existing system of word production which must be duly followed (Thrane 2009). If, peradventure, there are some formations that do not fit into this system, there should be a clear reason for this misfit.

I want to point out here that the prosodic use of some of these derived words in Yorùbá provides a kind of support for my claim, even though the words might not be utilised on a daily basis due to some conventional factors. For instance, the word halè-halè 'he who threatens', and didó-dídó 'he who mends a broken mortal', are rarely used on daily basis. However, both have been used without any disclaimer at one point or the other in the literature.

In addition, I point out in this study that the reason why didó-dídó is not conventionally utilised by the language users might be because of its homonymy status because it could also mean the act of having sexual intercourse; derived from dó 'to have sexual intercourse'. The Yorùbá language users see this word as a vulgar expression and would rather avoid it in the day-to-day language use.

One other factor that might account for the reason why some duplicative derivations may not be approved in the language may not be unconnected with some of the status of the object of the VP. 
For instance, let us consider (14):
(14) ja olè
jalè
jalè jalè
jalè-jalè
rob thief
rob-thief
rob rob
'robber'

In (14), the derived nominal jalè-jalè is not used in the language even though it is syntactically derivable. The explanation I give for this is that the object of the VP ole 'thief' is in itself an agentive nominal. The same explanation goes for the non-occurrence of a word like láhun-láhun, supposedly to mean a miser.

The second hypothesis, which I propose here, is that, it is possible that there is a covert nominaliser, which nominalises the reduplicated VP at the interface during the process of agentive reduplication. The fault to this claim would be that, if actually there is a covert nominaliser, there should not be any need for reduplication before we can derive the nominal. Nominals that have covert nominalisers do exist in the language. I present the following words in the language to support this assertion:
(15) a. kòjèggbin
$\emptyset$-kò-jẹ-ẹgbin
Nom-neg-eat-dirt
does-not-eat-dirt
'foot arch'
b. Yémiítàn
$\varnothing$ yé mi í tàn
Nom neg-1 sg-HTS-deceive
stop deceiving me
'an àbíkú name' 
The examples in (15) show the process of deriving nominals by prefixation even though the prefixes are not overt. Therefore, I claim that such nominals as in (15) above possess a covert nominaliser.

However, this is not the case for a reduplication process as the reduplicant acts as the nominaliser. If the root of a duplicated item is nominalised by a covert prefix, the derived items would still have had a verbal status thus ránșo 'sew cloth' and peja 'kill fish'.

Going by this, out of the two hypotheses proposed, even with few cases of exceptions, the first hypothesis seems to fare better. I therefore claim in this study that the left-sided copy in a reduplicative nominal is an agentive nominaliser, which nominalises the VP it merges with.

\subsection{Headedness in Yorùbá Reduplication}

In this section, I discuss how head is determined in the reduplication type that I have analysed so far in this study. In doing this, I shall exploit two ideas of headedness; namely, syntactic driven headedness and semantic driven headedness. The importance of this phenomenon hinges on the distinctive nature of the kinds of reduplication under discussion in this study.

Syntactic driven headedness is highly dependent on endocentricity during the process of deriving a nominal through merge. Merge, one of the properties of the Minimalist Programme, is a set formation operation that forms a higher syntactic set from the combination of binary syntactic items.

(16)

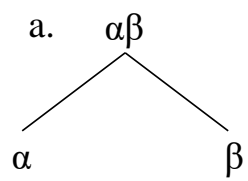

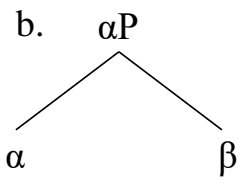

$\beta$

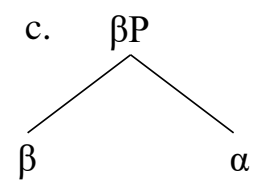


What endocentricity explains is that when two elements merge, the resulting phrase takes its label from one of the merged elements (Ilori 2010, Adger \& Svenonius 2011, Collins 2011). The endocentric feature allows the resulting phrase to be labelled after $\alpha$ or $\beta$ in (16b) and (16c). Consequently, the element that contributes to the phrasal category possesses the headedness feature of the nominal derivation.

Note that the agentive reduplication derivation justifies this claim, as discussed and exemplified earlier in this section.

Consider (17):
a. pẹja-pẹja
killfish-killfish
'fisherman'
b. pààyàn-pààyàn
killhuman-killhuman
'killer'
c. gbẹ́nà-gbẹ́nà
carve-carve
'sculptor'
d. kộlé-kộlé
buildhouse-buildhouse
'builder'
e. kólé-kólé
parkhouse-parkhouse
'burglar'

The data sets in (17) show that the left-sided copies of the contributing morphemes are the heads of the nominal derivation.

This claim fulfils the endocentric feature present in nominal derivation. However, because of the need to nominalise the derivation, 
reduplication of the input morpheme is necessary. The reason why this is so is because the head position is never vacant at spell-out for this kind of derivation.

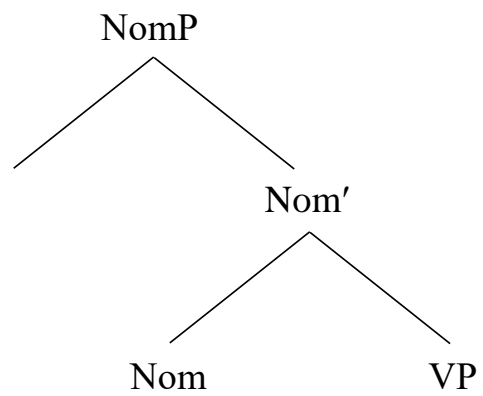

We see that the spec NomP is empty in the above structure because the head of the derivation, which could have occupied the position, is a functional category that nominalises the VP.

In contrast to this assertion, the headedness position in duplicative construction is not always occupied both before and during spell-out. This is a case of semantic driven headedness in derivation.

In essence, I claim that headedness in Yorùbá reduplication may actually not follow the same pattern, but it largely depends both on the syntax and semantics connotation of the derived nominal.

\subsection{Headedness in Yorùbá Noun-Noun Collocation}

There is a clear-cut difference between nominal derivation by compounding and nominal derivation by prefixation and reduplication. Compounding involves the collocation of two different nouns. It should be noted here that the collocating nouns in compounding are freestanding lexemes (Booij 2007, Omachonu 2015). The focus of this study is not to bring out the differences between compounding and 
other word formation processes in Yorùbá. What I intend to look into is what constitutes the head in the type of derived nominals under discussion.

In the bid to determine the head between two collocated nouns, I present two different approaches; namely, (i) Syntactic approach and (ii) Semantic approach. I examine the two approaches in determining headedness in Yorùbá compound.

\subsubsection{Syntactic Approach}

Analysis of the syntax of compounding could be either endocentric or exocentric. Endocentric analysis of compounding is a grammatical analysis that refers to a group of syntactically related words where one of the words is functionally equivalent to the group as a whole, and exocentric analysis explains a case where none of the words in a syntactically related structure is functionally equivalent to the group (Selkirk 1982; Crystal 2008: 169, 178).

In this paper, I propose that Yorùbá compound words are endocentric, i.e., they have heads and the head is one of the constituents that merge to derive a nominal construction.

Consider these:
a. ìyá-ìyàwó
mother-wife
'mother-in-law'
b. agbo-ijó
group-dance
'place of dance'
c. ọtí-ọkà
drink-corn
'corn-drink' 
In the above data sets, following the distributional criteria of endocentricity in the noun-noun collocation, I claim that the first nouns in the examples above are the head of the constructions.

There are two important points about headedness in the syntax of noun-noun compounding. First, the first element in the derived nominal could take another element as complement and it will not lose its headedness feature.

Let us examine (20):

(20) a. i. ìyá-ìyàwó

mother-wife

'mother-in-law'

ii. ìyá-arúgbó

mother-old

'old-woman'

b. i. agbo-ijó

group-dance

'dance floor'

ii. agbo-màlúù

group-cattle

'cattle ranch'

In (20a) and (20b), iyá and agbo are analysed as the head, because they take different complements and they prevail on the overall meaning of the derived nouns. The second important thing to note is that if the position of the constituent that is referred to as head is changed, it immediately loses its headedness feature. 
Consider (21):

(21) a. i. ìyá-àgbà

mother-old

'old-woman'

ii. àgbà-ìyà

old-bad

'old-fool'

b. i. ọkà-bàbà

corn-lead

'guinea-corn'

ii. ọtí-ọkà

drink-corn

'corn-drink'

In (21ai) ìyá is the head of the derived nominal, and àgbà is the complement. However, in (21aii), àgbà occupies the initial position, and its complement feature changes to headedness. Same is the case with okà in (21bi) and (21bii).

What this entails is that in the syntax of compound nominals in Yorùbá, the first noun which occupies the initial position in the structure is the head of the compound nominal.

The diagram below expatiates the claim:

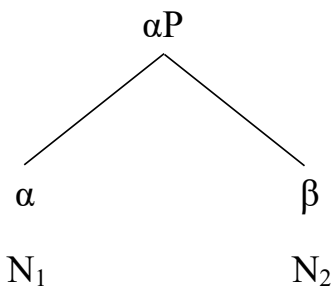


What is shown in the structure in (22) is that the $\alpha$ position is the head position in any construction involving $\mathrm{N}-\mathrm{N}$ collocation in Yorùbá, and it is this first noun that projects to the phrasal level.

(23)

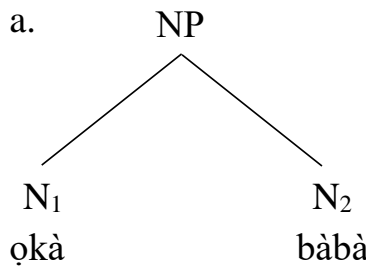

b.

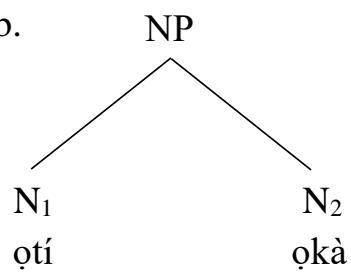

The structures in $(23 \mathrm{a} \& \mathrm{~b})$ show that the $\mathrm{N}_{1}$ position is the head position since the change of the syntactic objects does not affect the structure in respect to the headedness positioning.

Going by the position occupied by the head in each word formation strategy in Yorùbá, it could be concluded that derived nominals in the language are left-headed endocentric constructions.

\subsubsection{Semantic Approach}

The semantics of a derived nominal can be used to identify the head of the construction. It is important to note at this stage that the semantics of a derived nominal compound is supposed to be a new meaningful concept, although with meanings from the two nouns that are collocated. Under the semantic approach, the meaning of a compound word appears to be an extension of one of the contributing nouns. In this view, the noun, which has salient meaning the nominal compound exhibits, is strongly considered as the head.

Let us consider the following: 
(24) a. ìyá-ọkọ mother-husband 'mother-in-law'

b. ọjà-alẹ́ market-night 'night-market'

c. ẹran-oko animal-bush 'bush-animal'

d. ilé-ẹ̀kọ́ house-study 'school'

The data sets presented in (24) all show that the semantics of the collocation is embedded in the first noun. In (24a) İyá is a feminine character that takes oko as the complement; the mother-in-law is a mother who has a relation with the husband, but not the other way round. Just as much as the second noun does not have a feminine feature and it is not a mother, therefore, it cannot be the head of the nominal compound.

Similarly, in (24b), ojà-alé is a market where buying and selling takes place at night. This means that it is a type of market just as ojàoko 'village market'. In the same vein, ile-ẹkó in (24d) is a type of house where studying is being carried out. This suggests that the meaning is in the noun 'house' and not 'study'. In a noun-noun collocation, therefore, the head of the two nouns is the one that takes a semantic lead, the one that supplies the salient meaning and this always happens to be the first noun in case of the Yorùbá language. 


\subsection{Compounding: The Minimalist Programme Approach}

The nature of the process of the compounding in relation to the Minimalist Programme makes the analysis appear as a singular action of merge between the participating nouns. Some scholars have proposed some further syntactic action to make the derivation converge. One of such works is Roeper et al. (2002), which proposes root-compounding parameter. What this proposal claims is that there exists what is referred to as a set merger between $\mathrm{N}_{1}$ and $\mathrm{N}_{2}$ in which $\mathrm{N}_{1}$ takes $\mathrm{N}_{2}$ as a complement and then followed by the movement of the $\mathrm{N}_{2}$ to adjoin $\mathrm{N}_{1}$ by pair-merger to the root of the compound. I claim in this study that there is no movement of any kind in the derivation of compounding in Yorùbá, going by the Minimalist framework. This is due to the absence of a functional category that allows any form of movement (Mukai 2004). In addition, movement of any kind during this process would violate the principle of economy. However, it is important to note that there are potent activities at the interface where the LF and PF representations take place. The role of these representations is to connect phonological features with cognitive features of a construction after spell-out and this is a vital operation in compounding because compound nominals have different semantic representations.

In most N-N constructions in Yorùbá, it is not automatic for phonological processes to occur. However, if the need arises for them, two major phonological processes, namely vowel elision and assimilation, are eminent since there is mostly the case of vowel hiatus at lexical borders in the compound structure of the language.

Consider the following: 
(25) a. i. ilé-ọtí

house-drink

'pub'

ii. ojú-ọ̀run

eye-heaven

'sky'

iii. ore-ọfẹ́

favour-free

'grace'

b. i. ilé-ìjọsìn (iléèjosìn)

house-worship

'church'

ii. bàbá-ìjọ (bàbáàjọ)

father-crowd

'church elder'

iii. àgbà-ìyà (àgbààyà)

elder-bad

'old-fool'

c. i. ìyá-ọkọ (ìyákọ)

mother-husband

'mother-in-law'

ii. ojú-òde (ojúde)

eye-outside

'balcony'

iii. ọtí-ọkà (ọtíkà)

drink-corn

'corn-drink'

In (25a), the examples do not go through any phonological process but in (25b) and (25c), the nominal compounds go through assimilation 
and deletion respectively. This is the reason why it is crucial for the LF representation to be actively involved after spell-out.

The vowels in hiatus in the examples in (25b) and (25c) follow some particular pattern in the structure. However, since it is not my focus to analyse this pattern, I shall not really dwell on this.

What is claimed in this section is that operation merge is responsible for the construction of nominal compound and that no form of movement is required for the convergence of the nominals.

\subsubsection{Parallel Analysis of the Head in Yorùbá Nominalisation Processes}

The main approach I shall employ to provide a unified analysis of the three types of nominalisation in Yorùbá is the headedness approach. I shall identify the headedness status of the different participating morphemes in each of the derivation processes. It is important to note here that 'merge' is the major operation responsible for the attachment of a prefix to the root, a reduplicated copy with the root word and the collocation of the two nouns in compounding. However, while the process effects changes in word class category in prefixation and reduplication, compounding is a non-categorial changing word formation process.

Furthermore, language internal evidence suggests that syntactic analyses should be accounted for in the same way. Therefore, I shall employ the process used for the analysis of nominals derived by prefixation to analyse reduplication. I claim that prefixes have nominal features and that they are nominalisers that nominalise V/VP. Going by this assertion, I claim that there is a categorical difference between the root and the reduplicant in reduplication. This reduplicant nominalises the VP, so it has a nominal feature.

Let us consider the following: 
118 Typology of Headedness in Yorùbá Nominal Derivations

(26) a. apẹja

a-pẹja

PREF-kill-fish

'fisherman'

b. pẹjapẹja

pẹja peja

RED-kill.fish

'fisherman'

(27) a. adaran

a-daran

PREF-guide-goat

'shepherd'

b. darandaran

daran daran

RED-guide-goat

'shepherd'

(28) a. òpùrọ́

Ò-purọ́

PREF-tell.lie

'liar'

b. purọ́purọ́

purọ́ purọ́

RED-tell.lie

'liar' 
(29)

$$
\begin{aligned}
& \text { a. ọdọ́kọ } \\
& \text { ò-dọ́kọ } \\
& \text { PREF-sex(v)-man } \\
& \text { 'promiscuous lady' } \\
& \text { b. dọ́kọdọ́kọ } \\
& \text { dọ́kọ dọ́kọ } \\
& \text { RED + sex(v)-man } \\
& \text { 'promiscuous lady' }
\end{aligned}
$$

The nominalising positions in (26a), (27a), (28a) and (29a) are filled with prefix vowels while the same positions in (26b), (27b), (28b) and (29b) are filled with reduplicated roots. Apart from the fact that these two variables could occupy the same position in the derivation, they both have the same semantic connotation; namely, agentive meaning. There is no semantic difference between, for instance, (26a) and (26b), and (29a) and (29b). It is on this note that I propose that both the prefix and the reduplicant possess the same function in the nominal derivation. Therefore, both of them are analysed as the head of their respective derivations. By extension, the relationship between the two nouns in compounding has been seen to be similar to what holds in prefixation and the VP reduplication. Whereas the latter process is class changing, the former is class maintaining.

The premise on which this process is considered a nominalisation process is that the derived nominal is different from the two nouns that are merged to form the nominal. I base this notion on the idea developed by Omachonu \& Abraham (2012), which claims that the nominals derived by compounding are different from any of the two nouns that are merged to derive the nominal. In furtherance of this, I claim in this study that due to the endocentric nature of the derived 
nominal, one of the merged nouns acts as the nominaliser of the other noun. By the syntactic and semantic approaches used to analyse the status of the two nouns in compounding, the first noun is claimed to possess the salient meaning of the derived nominal. It is also the first noun that projects to the phrasal level. Therefore, it is considered as the head of the construction.

Consider the following:

(30) a. ìyá-ọkọ

mother-husband

'mother-in-law'

b. ẹran-ìgbẹ́

meat-faeces

'bush meat'

c. ọmọ-ọ̀dọ̀

child-side

'house-maid'

In the above examples, all the first nouns are considered the head of the constructions; they are the nouns that project to the phrasal level, the nouns that possess the connotative meaning of the derived nominals, and by implication, these nouns modify the entire nominal construction. On this note, I present a unified structure for nominal derivation by prefixation, reduplication and compounding.

Let us consider the tree diagram below: 
(31)

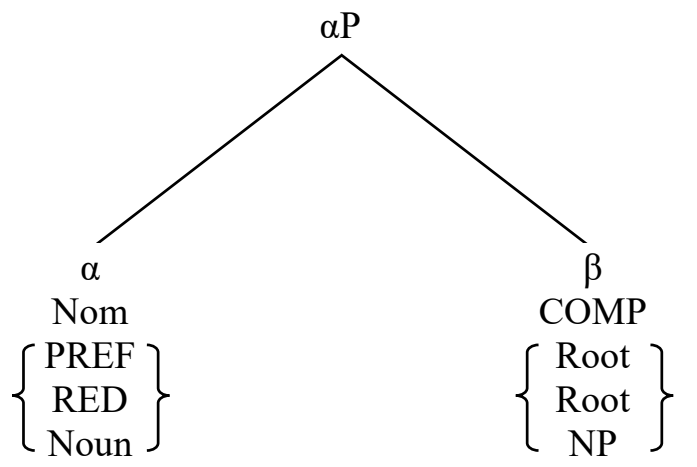

The structure in (31) shows $\alpha$ as the nominaliser and head of the derived nominal. It takes $\beta$ as its complement. When the $\alpha$ is a prefix or reduplicant, it takes the VP as its complement. However, if the head is a noun, the complement is an NP. The structures in (32) illustrate further what is presented in (31) above.

(32)

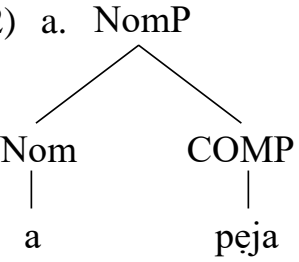

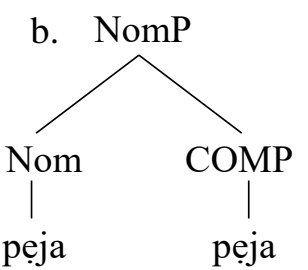

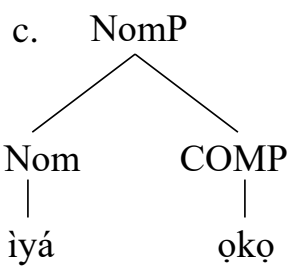

All the derived nominals in (32) are headed by their nominalisers and they project their phrases. I can therefore conclude that all Yorùbá derived nominals are headed by the first component in the structure, and that they are base generated. 


\section{Conclusion}

In this study, I have made attempts to establish that the three noun formation processes in Yorùbá possess a parallel representational structure. This is exemplified with the unification of the different analysis of the three nominalisation processes in Yorùbá. Through the headedness account, it is shown that the determination of the head in the morphosyntax is mostly endoncentric because one of the merging morphemes is confirmed to be the head in the derivation as projected in the phrasal level. Furthermore, the head analysis of the derivation shows that the first morpheme is actually the head of the derivation in the nominalisation processes by prefixation, reduplication and compounding.

\section{References}

Adger, D. \& P. Svenonius. 2011. Features in Minimalist Syntax. In C. Boeckx (ed.), The Oxford Handbook of Linguistic Minimalism 27-51. Oxford: Blackwell.

Ajibóyè, O. \& R. Déchaine. 2004. The Syntax and Semantics of Yorùbá Duplicative Constructions. Paper Presented at the 35th Annual Conference on African Linguistics, Harvard University. Ajíbóyè, O.., R. Déchaine \& O. Stewart. 2003. On the Syntax of Nominalisation in Ėdó and Yorùbá. Kinyira Njira 23-42.

Akinlabi, A. \& I. Iloene. 2015. High Vowel Alternations in Igbo (Olo Ezeagu) and Yorùbá. In Ọ. Orie et al. (eds.), Current Research in African Linguistics: Papers in Honour of Oladele Awobuluyi 116139. Cambridge: Cambridge Scholars.

Awóbùlúyì, O. 2008. Ẹkọ́ İṣẹdá-Òrọ̣ Yorùbá. Àkúrẹe: Montem 


\section{Paperbacks.}

Awóyalé, J. 1974. Studies in the Syntax and Semantics of Yorùbá

Nominalisation. Unpublished Ph.D. Dissertation, University of Illinois.

Awóyalé, Y. 1989. Reduplication and the Status of Ideophones in

Yorùbá. The Journal of West African Languages 19, 15-34.

Bakovic, E. 2003. Vowel Harmony and Stem Identity. San Diego Linguistic Papers 1, 1-42.

Booij, G. 2007. The Grammar of Words. An Introduction to Linguistic Morphology. 2nd edition. Oxford: OUP.

Caesar, R. 2019. A Morphosyntactic Analysis of Dangme Allusive

Names. Journal of Universal Language 20.2, 53-93.

Chomsky, N. 2001. Derivation by Phase. In M. Kenstowicz (ed.), Ken

Hale: A Life in Language 1-52. 2nd edition. Cambridge, MA: MIT Press.

Citko, B. 2005. On the Nature of Merge: External Merge, Internal Merge, and Parallel Merge. Linguistic Inquiry 36, 475-496.

Collins, C. 2011. Introduction to Minimalist Syntax. Paper Presented at the African Linguistic School, Porto-Novo.

Collins, C. 2013. Introduction to Minimalist Syntax. In The African Linguistics School Lecture Handout. Ibadan: African Linguistics School.

Crystal, D. 2008. A Dictionary of Linguistics and Phonetics. Oxford: Blackwell.

Ehineni, T. 2017. Prosodic Reduplication in Yorùbá. Journal of Universal Language 18.2, 39-59.

Eleshin, A. 2017. A Unified Account of Nominalisation in Yorùbá

Language. Ph.D. Dissertation, University of Lagos.

Forza, F. 2011. Doubling as a Sign of Morphology: A Typological

Perspective. Journal of Universal Language 12.2, 7-44. 
Ilori, J. 2010. Nominal Constructions in Igala and Yorùbá. Unpublished Ph.D. Dissertation, Adekule Ajasin University.

Lyons, J. 1980. Chomsky. Milano: Rizzoli.

McGilvary, J. 2014. Chomsky, Language, Mind, Politics. Cambridge: Polity Press.

Mukai, M. 2004. Headedness of Compound Words in Minimalist Framework. Ms., University of Durham.

Ògúnkẹ́yẹ, O. 2002. A Lexicalist Approach to the Study of Aspects of Yorùbá Morphology. Unpublished Ph.D. Dissertation, University of İbàdàn.

Ògúnwálé, J. 2012. A Pragmalinguistic Study of Yorùbá Personal Names. Journal of Literary Onomastics 2, 24-35.

Ola, Ọ. 1995. Optimality in Benue-Congo Prosodic Phonology and Morphology. Ph.D. Dissertation, University of British Columbia. Omachonu, G. 2015. Headedness and Demarcation between Nominal Compounds and Noun Phrase Ígálà. In Ọ. Orie., J. Ilọri \& C. Yuka (eds.), Current Research in African Linguistics 411-433. Cambridge: Cambridge Scholars.

Omachonu, G. \& D. Abraham. 2012. Compounding in Igala: Defining Criteria, Forms and Functions. Unizik Journal of Arts and Humanities 13, 184-206.

Owólabí, K. 1976. Noun-Noun Construction in Yorùbá: A Syntactic and Semantic Analysis. Unpublished Ph.D. Dissertation, University of Ìbàdàn.

Owólabí, K. 1984. Ìsọ̀rí Ộọ̀ Orúkọ tí a Șẹ̀dá Nípa Lílo Àfòmọ́-İbẹ̀rẹ àti Atọ́ka Àfikún nínú Ėdè Yorùbá. Laangbasa 1, 61-101.

Owólabí, K. 1985. Àpètúnpè Gẹegẹ bí Ète fún İṣẹdá Ộọ̀-orúkọ nínú Èdè Yorùbá. Laangbasa 2, 69-102.

Oyèláràn, O. 1987. Ộnà kan kò wọjà: Mọfọ́lọjì Èdè Yorùbá. Journal of the Yoruba Studies Association of Nigeria 1, 25-44. 
Pulleyblank, D. 2009. Patterns of Reduplication in Yorùbá. In K. Hanson \& S. Inkelas (eds.), The Nature of the Word: Studies in Honour of Paul Kiparsky 311-357. Cambridge, MA: MIT Press. Pulleyblank, D. \& A. Akinlabi. 1988. Phrasal Morphology in Yorùbá. Lingua 74, 141-166.

Roeper, T. et al. 2002. Learnability in a Minimalist Framework: Root Compounds, Merger, and the Syntax-Morphology Interface. In I. Lasser (ed.), The Process of Language Acquisition 25-35. Frankfurt: Peter Lang Verlag.

Selkirk, E. 1982. The Syntax of Words. Cambridge, MA: MIT Press. Taiwo, O. 2006. Mofọ́lọjì. Ìbàdàn: Lay of Venturs Publishing Educational Service.

Táíwò, O. 2014. The Morpho-Syntactic Interaction and the Derivation of Nominal Compounds in Yorùbá. International Journal of Language Studies 8, 49-74.

Thrane, T. 2009. The Language Faculty-Mind or Brain? Journal of Language Research 7, 1-42. 